\title{
BioéthiqueOnline
}

\section{Individual and Collective Responsiveness to Climate Change: A Response to Dwyer}

\section{Cheryl C Macpherson}

Volume 5, 2016

URI : https://id.erudit.org/iderudit/1044259ar

DOI : https://doi.org/10.7202/1044259ar

Aller au sommaire du numéro

Éditeur(s)

BioéthiqueOnline

ISSN

1923-2799 (numérique)

Découvrir la revue

Citer cet article

Macpherson, C. C. (2016). Individual and Collective Responsiveness to Climate Change: A Response to Dwyer. BioéthiqueOnline, 5.

https://doi.org/10.7202/1044259ar
Résumé de l'article

L'histoire de James Dwyer au sujet d'une Commission GAIA fictive met en évidence les préoccupations concernant la portée de la bioéthique, en particulier en ce qui concerne la répartition de la responsabilité au niveau international face aux impacts des changements climatiques sur la santé. Ce commentaire traite de l'impact potentiel d'un individu sur les émissions de gaz à effet de serre et l'importance des réponses institutionnelles afin d'avoir un impact significatif. 


\title{
Individual and Collective Responsiveness to Climate Change: A Response to Dwyer
}

\author{
COMMENTAIRE / COMMENTARY \\ Cheryl C Macpherson ${ }^{1}$
}

Reçu/Received: 6 Jan 2016

Éditrices/Editors: Maude Laliberté \& Aliya Affdal

Publié/Published: 13 Jan 2016

Travail creatif discuté/Creative Work discussed: J. Dwyer. The Gaia Commission BioéthiqueOnline 2014, 3/18

2016 CC Macpherson, Creative Commons Attribution 4.0 International License

\begin{abstract}
Résumé
L'histoire de James Dwyer au sujet d'une Commission GAIA fictive met en évidence les préoccupations concernant la portée de la bioéthique, en particulier en ce qui concerne la répartition de la responsabilité au niveau international face aux impacts des changements climatiques sur la santé. Ce commentaire traite de l'impact potentiel d'un individu sur les émissions de gaz à effet de serre et l'importance des réponses institutionnelles afin d'avoir un impact significatif.
\end{abstract}

\section{Mots clés}

changement climatique, responsabilité individuelle, responsabilité collective

\section{Summary}

James Dwyer's story about a fictional GAIA Commission highlighted unresolved concerns about the scope of bioethics, specifically regarding the global distribution of, and responsibility for, the health impacts of climate change. This commentary discusses the potential impact of an individual on greenhouse gas emissions and the importance of engaging institutional responses in order to have meaningful impacts.

\section{Keywords}

climate change, individual responsibility, collective responsiveness

Affiliations des auteurs / Author Affiliations

${ }^{1}$ Bioethics Department, St George's University School of Medicine, St George's, Grenada

Correspondance / Correspondence

Cheryl C Macpherson, ccox@sgu.edu

\section{Conflit d'intérêts}

Aucun déclaré

\section{Conflicts of Interest}

None declared

\section{Preamble}

James Dwyer's story about a fictional GAIA Commission [1] highlighted unresolved concerns about the scope of bioethics; the global distribution of, and responsibility for, health impacts of climate change; and the limited success of bioethics in applying principles and theories of justice to practical problems like climate change that involve both health and resources essential to health. I share these concerns $[2,3,4]$ and have a related book forthcoming in which Dwyer is a contributor [5].

\section{Commentary}

In the story, the GAIA Commission brought charges of "recklessness, negligence, and indifference" against many who contributed to the ruin of Earth's climate, leaving readers to wonder what type of world remains after such devastation. Although the worst offenders were "the politicians who denied evidence, catered to special interests, and delayed necessary steps; and all the business people who sowed doubts, camouflaged their intentions, and made millions by destroying the future", the story focuses on Francis, a bioethicist. Francis had lived a more carbon neutral lifestyle than most North Americans, except for his flights to speak at conferences about "justice, responsibility, and responsiveness". When asked "What were you people in bioethics thinking? You flew all over the world emitting tons of carbon to talk about individual autonomy, informed consent, and rationing ventilators", Francis acknowledges that his efforts were "too little, too late" and that he "didn't respond adequately to the big problem." 
The story seems designed to provoke thought and discussion among bioethicists, philosophers, and other readers about their responsibilities to those harmed by greenhouse gas emissions generated through their respective actions and inactions. Such thought is sorely needed in bioethics and academia, and across all disciplines and sectors. Philosopher James Garvey [6] explains that our concept of what constitutes a meaningful life helps shape our individual responses to climate change. In my own life, limiting my use of energy, food, and water is consistent with values I learned from my depression era grandparents. Doing so does not feel like a sacrifice, it feels like living a good life.

In Dwyer's story, the implication that Francis should have responded adequately "to the big problem" disturbs me. Climate change is a big problem that cannot be rectified by a single individual. It requires a vast scale of emissions-reducing actions by industries, institutions, and commercial enterprises. Governments can and should help, but Francis cannot singlehandedly make such changes. Moreover, it's not clear that the adequacy of Francis's response can be fairly or accurately measured. Would an adequate response from Francis be equally adequate from a banker, lawyer, or Chief Executive Officer? What about from a factory worker, waitress, or homeless person?

Answers to questions about how to determine i) who to hold accountable for past or current emissions; ii) which harms can and should be ameliorated; and iii) who should rectify those harms, how, and when, should be answered with objective and accurate scientific, economic, and other forms of evidence. In theory, reasonable answers to such questions could come through academia, government, industry, and public deliberation. In practice, it may be impossible to attain genuine understanding of the evidence and uncertainties, or genuine consensus about the implications and ways forward. The consensus outcome of the 2015 United Nations COP21 is immensely encouraging, but may also be too little, too late.

In any case, individual responses against emissions are valuable in several ways, but are not enough. Globally, the largest source of emissions is industrial production and combustion of fossil fuels [7]. On practical and ethical levels, instead of trying to hold individuals like Francis accountable, we need to look upstream. Focusing on internal and external policies to regulate emissions produced by industries and institutional practices is more fair and effective than focusing on individuals [8], except perhaps for focusing on individual leaders of institutions and governments.

Dwyer's story also suggests that individuals are less guilty for emissions they generate in the process of trying to reduce overall emissions and persuading others to do so. Determining this would require designing means of measuring and weighing both guilt and overall emissions-reductions, itself quite a challenge. Changes in attitudes and actions typically evolve with time and circumstance, so how might we weigh the emissions produced during a flight to speak about emissions-reductions? Would it vary for larger or smaller audiences, or for receptive or unreceptive audiences? One particular speaker has influenced my climate work more significantly than others. Would his flight-related emissions accrue less guilt than those of the others? If so, by how much? Ewan Kingston [9] offers insights about the ways in which such questions, and their answers, may be helpful.

Many reflect about the emissions they generate through their own transportation and consumption patterns. This may reduce their lifetime emissions, and help to fulfill their concepts of living good lives. Targeting them and other individuals who purchase airline seats, however, is misguided because airlines, airports, and those who run them have much greater authority and resources with which to meaningfully reduce emissions. Airlines and airports could do this relatively easily, while maintaining exorbitant profits for their shareholders and executives, by mandating recycling to reduce the vast quantity of solid waste produced during a single domestic flight, or a single day in an airport. With their buying power, they could pressure their contractors to deliver sustainably sourced products and foods; their engineers to deliver more energy efficient computers, airplanes, and equipment; and their executives to implement other carbon neutral corporate practices. This is why political activism (mentioned briefly in Dwyer's story) may be helpful. 
Dwyer's Gaia Commission reminds us that it is important for individuals to reflect on how their actions and inactions generate emissions, and whether and how to meaningfully reduce their emissions. In the real world, however, efforts to reduce emissions and hold the biggest contributors accountable should focus on industries, institutions, and governments. Their influence and resources position them to make an immense difference for themselves and the rest of the world. Meanwhile, they might like to thank Francis and emulate his efforts to live a good life, reduce his own emissions, and persuade others to do the same.

\section{List of References}

1. Dwyer J. The Gaia commission: Climate Change and Moral Responsibility. BioéthiqueOnline $2014 ; 3 / 18$

2. Macpherson CC, Akpinar-Elci M. Caribbean heat threatens health, well-being, and the future of humanity. Public Health Ethics 2015; doi:10.1093/phe/phv008

3. Macpherson CC. Climate change is a bioethics problem. Bioethics 2013; 27(6): 305-308. doi:10.1111/bioe. 12029

4. Macpherson CC. Climate change matters. J Medical Ethics 2014; 40(4): 288-290. doi: 10.1136/medethics-2012-101084

5. Garvey J. The Ethics of Climate Change. Continuum International Press, NY. 2010. 192 p.

6. Patz JA, Frumkin H, Holloway T, Vimont DJ, Haines A. Climate Change: Challenges and Opportunities for Global Health. JAMA 2014; 312(15):1565-1580.

7. Holland A. Must we give up environmental ethics? In: Environmental Ethics and International Policy. ED HAMJ ten Have. 2006. 117-143. UNESCO.

8. Macpherson CC. 2016. Ed. Climate Change and Health: Bioethical Insights into Values and Policy. Public Health Ethics Series. Springer Press, Dordrecht (forthcoming).

9. Kingston E. Climate Change as a Three-Part Ethical Problem: A Response to Jamieson and Gardiner. Science and Engineering Ethics 2014; 20(4):1129-1148. 